\title{
Sustainable management of NHS assets backlog maintenance
}

\begin{abstract}
Purpose - Lord Carter's 2015 'Independent Review’ stated that to improve NHS England's efficiency, operational productivity should be targeted in four main areas, one being estates management. NHS England's estate includes a variety of buildings some of which are considered no longer fit-forpurpose, thus creating risk to patients and staff. These built assets require continuous maintenance, adding pressures to NHS England's precarious financial situation. The aim of this paper is to identify positive strategies and major constraints to achieving sustainable management of backlog maintenance across the NHS assets, and thus suggest balanced actions.

Design/methodology/approach - The research adopts a qualitative approach and combines: literature review of current backlog maintenance methodologies; interviews with Estates and Facilities Directors from seven NHS Trusts on backlog maintenance strategies; and a NHS Trust detailed case study.

Findings - The major finding is that sustainable management of backlog maintenance is achievable if there is a consistent, pro-active and long-term strategic approach where critical levels of backlog maintenance are prioritised. Additional issues (i.e. appropriate methodology, performance metrics and links with clinical service delivery strategies) also need to be considered.

Practical implications - This study is relevant to the management of the NHS estate including development and adoption of sustainable strategies.

Originality/value - This paper offers original insights to the factors influencing healthcare estates' backlog maintenance at a time when the UK policy agenda is targeting infrastructure operational efficiency and organisations are seeking more comprehensive methodologies.

Keywords - Backlog maintenance, Asset management, Strategy, Healthcare, Critical Infrastructure, Risk

Paper type - Research paper
\end{abstract}

\section{Background}

The National Health Service (NHS) is one of the largest building landlords in the UK and responsible for assets worth over £84bn (Baillie, 2013). The value of its property, plant and equipment (including owned, leased and $\mathrm{PFI}^{1}$ contracts) was £48,266,225 during 2011-12, of which $69 \%$ accounted for buildings (Department of Health, 2012a). However, much of this is either surplus to requirements or outdated. In England, approximately 22\% of NHS acute hospital buildings pre-date 1948, and 25\% of buildings were built between 1948 and 1974. The NHS estate's rich collection of building typologies ${ }^{2}$ with different age profiles presents a challenge to sustainable asset management.

\section{Financial constraints}

In 2009: NHS annual maintenance costs were $£ 7.3$ billion (Appleby et al., 2009; Harker, 2012; Baillie, 2013); NHS buildings faced $£ 4.04$ billion maintenance backlog (West, 2009); and $£ 1.2$ billion was needed to eliminate only the high and significant (i.e. Critical) backlog risks (Department of Health, 2012b). Despite the reduction of the total size of the NHS estate due to restructuring and rationalising, the overall cost to eradicate backlog maintenance remained at $£ 4.04$ billion for 2013-14 (Department of Health, 2014). The actual investment to reduce backlog maintenance in 2013/14 was below £317,607,115, which corresponds to an approximate increase of 19\% from 2010/11.

\section{Risk of harm}

Healthcare buildings change rapidly and frequently, thus leading to space becoming not-fit-for purpose with: potential impact on heath service provision; increase in risk of harm to patients and staff; and no longer sustainable economic implications (Baker et al., 2004). Prolonged reductions in

\footnotetext{
${ }^{1}$ Private Finance Initiative (PFI) is a model of Public Private Partnerships used in the NHS England which are typically design-build-finance-operate.

${ }^{2}$ The NHS estate is diverse and includes many building types: Nightingale buildings, tower buildings, open and closed courtyards, Best Buy design, Harness design, Nucleus design and modular buildings.
} 
investments at a time when estate assets are becoming older and outdated have exacerbated the situation and placed the NHS under high scrutiny over the recent years. The Francis Report (2013) and Keogh Review (2013) provided evidence and in-depth validation of risks of probable future incidents still being a national challenge.

\section{Limited efficiency}

Lafond (2015) reported that $81 \%$ of Acute Trusts were in deficit by September 2014, despite the Department of Health (DH) setting the NHS a target in 2010 of $£ 20$ billion savings by 2014, with reinvestment of the savings to improve quality and raise productivity (DH/NHS Finance Performance and Operations, 2010). To improve NHS efficiency and close the increasing $£ 30$ billion/year spending gap resulting from growing demand and limited efficiency gains (NHS, 2014), Lord Carter's Independent Review (2015) determined that operational productivity should be targeted in four main areas, one of which is estates management.

\section{Aim}

This paper aims to identify positive strategies and major constraints to sustainable management of backlog maintenance and suggests balanced actions across NHS built assets to deal with the increasing need driven by ageing assets during a period of financial constraints. This paper draws on the findings of research into "Critical Infrastructure Risk" (CIR) and compares these outcomes with current approaches towards Trusts' maintenance management within their overall asset management strategies.

The paper is structured as follows. First, available definitions of backlog maintenance are introduced prior to focussing on healthcare assets, for which two methodologies are analysed. Next, the findings of the interviews and detailed case study are presented. The resulting discussion reveals six emerging balanced actions for sustainable management of NHS assets backlog maintenance. Finally, a long-term approach of NHS Trusts capital assets in accordance to their unique strategy is advocated.

\section{Methodology}

The six months' research comprised:

- literature review of the methodologies currently used to measure backlog maintenance;

- interviews (and subsequent data analysis) with Director of Estates and Facilities from purposefully selected NHS Trusts on backlog maintenance and definition of CIR; and

- an investigation of best practices via Chesterfield Royal NHS Foundation Trust detailed case study (DCS).

A mixed method sampling strategy (i.e. probability sampling and purposive sampling) was adopted to increase external validity and transferability of the research findings (Teddlie and Yu, 2007), as described below.

In collaboration with $\mathrm{DH}$, publicly available data (e.g. income, backlog and age), NHS Hospital Estates and Facilities Statistics (2006-2011) and income from 115 Trusts $^{3}$ was initial reviewed and a stratified sample of fourteen was selected for interview. Trusts were sampled from four categories: low income-low-backlog; low income-high backlog; high income-low backlog; and high income-high backlog. This provided the basis for stratification. Subsequently, Trusts were selected according to size (i.e. large, small, medium), function (i.e. teaching, non-teaching and specialist) and region (i.e. London, North-West, South-West, etc.).

The selected Trusts were invited to participate in the one-to-one semi-structured interviews, conducted via telephone due to their geographical spread and time constraints, and to reduce pressure on confidential issues (Burke and Miller, 2001; Novick, 2008). The interviews were designed to elicit: details of the Trust-specific approaches used and situational constraints; and their views on the results

\footnotetext{
${ }^{3}$ The quantitative data analysis of the 115 Trusts reported in Mills et. al. (2015) led to the understanding of the underlying nature of backlog maintenance, its accumulation, the age profile of the Trust, investment on backlog maintenance, the Trust income and their interrelation.
} 
of a quantitative study ${ }^{4}$ of their backlog maintenance spend in comparison to other benchmark Trusts. Seven agreed but this did not include any from the high income, low backlog category. Each interview lasted 30-45 minutes, during which participants: reflected on their self-reported backlog maintenance, with focus on high and significant risk; and their past, current and future strategies to eradicate CIR. The interviews were transcribed and coded using NVivo ${ }^{\circledR}$.

The quantitative study and interviews were used to test the initial hypothesis that "if backlog maintenance was eradicated and a Trust subsequently spent a fixed percentage of their annual income maintenance further backlog accumulation would be avoided”.

Chesterfield Royal NHS FT was selected as a DCS as it had consistently relatively low levels of critical backlog maintenance. This Trust took part in all of the phases of this research and volunteered to share further details of its asset management practice, to validate the findings from the interviews.

\section{Towards a definition of backlog maintenance}

\section{Defining maintenance}

There is variability in the way that maintenance is defined in the academic and practice-based literature. The Royal Institution of Chartered Surveyors (RICS) (2012) defined maintenance as "the combination of all technical and management actions needed to keep an asset in or bring it up to a suitable standard whereby it can perform its intended function at operational efficiency". This definition implies two processes: "retaining" to avoid failure (i.e "preventive maintenance" (PM)); and "restoring" after failure (i.e. "corrective maintenance" (CM)). PM includes planned preventive maintenance (PPM), condition-based maintenance (CBM) and statutory maintenance (SM) (Building Policy Unit, 2012). It has the advantages of costs distribution over time and of planned scheduled interventions which eases assets management over time; however, it can appear more expensive and requires a long-term plan where maintenance occurs at the scheduled moment. Whereas, CM includes unplanned corrective maintenance (UCM) and reactive maintenance (RM) (Building Policy Unit, 2012). CM has the substantial advantage, especially in this political and economic climate, of decreasing short-term maintenance costs, since the money will be paid out only when an urgent need arises, thus reducing maintenance interventions and the consequent disruptions to everyday operations and service delivery. However, CM has the disadvantage of increased risk, unforeseen and unplanned costs, and unplanned disruptions needing reactive urgent actions.

\section{Defining backlog maintenance}

Various definitions of backlog maintenance (BM) are available in literature for sectors other than healthcare infrastructure. For the purpose of this study, the review only considers methodologies currently used to measure backlog maintenance, of which the NHS Estates and the Queensland Health are reported below.

a) " $\mathrm{BM}$ is the cost to bring estate assets that are below acceptable standards in terms of their physical condition or do not comply with mandatory fire safety requirements and statutory safety legislation (as they apply to the built environment) up to an acceptable condition. Backlog relates to assets that are in need of some investment at the date of assessment. To establish the current condition of the estate, all the buildings in use for the support and delivery of healthcare should be assessed. [...] only owned assets should be included." (NHS Estates, 2004a).

b) "BM is essential maintenance work that has not been carried out and is deemed necessary to bring the condition of a maintainable asset up to a standard or acceptable level of risk that will enable the required service delivery functions of the asset to continue” (Asset Management Service Unit, 2010).

Both definitions refer to assets and continuity of service delivery according to regulations and standards, which highlights the strong relationship between backlog maintenance and clinical service delivery. However, neither definition appears to bring in 'levels' other than the whole asset, while other sectors (i.e. road infrastructure) associate BM to "single components, sub-assets or to the whole

\footnotetext{
${ }^{4}$ Prior to the interview date, each organisation was provided with an interview guide sheet, which included results of a quantitative study of their Trusts' backlog maintenance spend in comparison to other benchmark Trusts.
} 
road infrastructure asset” (Weninger-Vycudil et al., 2009).

The Queensland Health guidance recommends that both PM and CM strategies should lead to the detection of $\mathrm{BM}$, thus raising the argument whether identifying non-compliance (of a component) prior to failure should alone drive sustainable asset management actions or identifying noncompliance (of a component) after failure should be used to drive lessons learnt and best practices.

\section{Backlog maintenance in healthcare assets: methods and limitations}

The DH methodology ${ }^{5}$ assesses NHS estates condition and estimates "the likelihood and potential consequences of an undesirable event or potential failing occurring” (NHS Estates, 2004b). The specific five-year time-frame currently informs Trusts' strategies to identify and manage backlog.

According to the $\mathrm{DH}$, "Backlog is all the sub-elements, in which the 16 building and engineering elements are broken down, currently in condition $\mathrm{C}$ and below, for which major repair or replacement is currently needed. [...] It is all the sub-elements in contravention of one or more mandatory safety requirements and statutory safety legislation” (NHS Estates, 2004b).

The NHS risk assessment process combines relevant historical data and professional/technical judgement, which requires caution and objective judgement in data collection and management. RiskAdjusted Backlog is the sum of all risk-adjusted backlog costs for each building/block and external area relating to property occupied by the organisation, irrespective of ownership (NHS Estates, 2004b). The DH formula (see Equation 1) in the definition of 'non-critical backlog' takes into consideration the elements reported in Table I.

$$
\text { Risk-adjustedbacklog }(€)=\frac{\text { Non-critical backlog }}{\text { Remaining life of building/block }}+\text { Safety-critical backlog }
$$

The DH methodology should be used to estimate the amount of backlog and the cost of maintenance per building/block; however, the Estates Return Information Collection (ERIC) data are currently reported at a Trust estate level, which hinders detailed analysis. The DH methodology has been further subject to scrutiny as it adopts a " $5 \times 5$ criticality grid" that needs human judgement, advocating an assurance framework driven by "external defence systems" according to Langford (2009). However, to prioritise backlog maintenance, the Queensland Government also uses a similar "5x5 likelihood per consequence" matrix within its Computerised Maintenance Management System (CMMS), which comprises two separate parts: the functionality to "condition assessment"; and the functionality to "work order" (Asset Management Service Unit, 2010). The Facility Condition Index $(\mathrm{FCI})^{6}$ is used as a measure of performance to "compare relative building condition over a period of time”(Building Policy Unit, 2012). The Indian Health Service (IHS) guidelines for the distribution of Maintenance and Improvement (M\&I) funds to upkeep both federally-owned and tribal-owned buildings (Indian Health Service - OEHE, 2007). The M\&I funding allocation is distributed to: routine maintenance, estimated through factors applied to "current replacement cost", allowance for age, type of construction and use; M\&I projects, to reduce Backlog of Essential Maintenance, Alteration and Repair; environmental compliance, allocated annually on a priority of needs; and demolition, to reduce hazard and liability of Federally-owned buildings that are vacant or obsolete and no longer needed. To calculate routine maintenance funds allocation, IHS uses the Modified University of Oklahoma Formula (M-OUF) (see Equation 2) which takes into account the elements reported in Table I.

$$
M-O U F=[\text { space }] \times[\text { quarters }] / 4 \times[\text { construction index }] \times[\text { intensity }] \times[\text { location index }] \times[\text { replacement cost }]
$$

Among the elements taken into account to estimate routine maintenance, Table I identifies limitations in type (i.e. data access, data record or objective method) and level (i.e. asset, building or

\footnotetext{
${ }^{5}$ Each sub-element of the 16 building and engineering elements should be ranked according the conditions defined by A, B, B(C)+, C, D, X categories. This includes physical status and compliance with regulation, in the way that the ranking $\mathrm{B}(\mathrm{C})+$ corresponds to the ranking $\mathrm{B}$ that will fall below $\mathrm{B}$ within five years.

${ }^{6} \mathrm{FCI}=[$ total deferred maintenance $(\$) /$ asset replacement value (\$) $]$ x 100
} 
component). While the M-OUF routine maintenance formula relies on data at building level, the DH risk-adjusted backlog maintenance methodology includes estimation at asset, building and component level. This suggests that further issues remain unsolved, in addition to availability of relevant historical data and capability of professional/technical judgement (e.g. how to estimate the percentage of use of a building; how to manage the differences between owned and leased buildings; and how to compare within and across built assets).

\section{[insert table I]}

\section{NHS Trusts interview findings: positive CIR strategies and constraints}

All seven CIR interviews highlighted that NHS Trusts had a clear perception of how accumulated critical backlog impacts on infrastructure failures and incidents, thus affecting patients and staff safety. Table II summarises the findings from all seven Trusts interviewed from the three groups: Low Income - Low Backlog ( $\mathrm{n}=1)$; Low Income - High Backlog $(\mathrm{n}=4)$; and High Income - High Backlog $(n=2)$.

Analysis of the findings revealed what the Trusts perceived as positive strategies for, and major difficulties against, putting in place sustainable asset maintenance management strategies to: eradicate high and significant risk backlog maintenance; and prevent accumulation of medium and/or low risk backlog maintenance. The findings are presented in Table II and subsequently discussed.

\section{[insert table II]}

\section{Positive CIR strategies}

Good knowledge of individual asset's backlog levels and the main causes was demonstrated by most of the interviewed Trusts. The ERIC data returns were more accurate and complete when the Trusts had made available funding to deliver relevant staff training. A lack of methodological clarity and the use of external consultancies were suggested as reducing the accuracy of ERIC returns, thus demonstrating the strengths of in-house Trusts' knowledge.

Estate age profile and baseline backlog levels contribute to backlog maintenance accumulation, as older and unsuitable infrastructures tend to require more investments than newly built assets. When Trusts undergo substantial changes in floor area and/or age profile (e.g. after building disposal, site merger or a new build) there can be significant impacts on critical backlog, which may appear if the ERIC data are used on their own. The relationships between average annual spent on critical backlog maintenance as a percentage of the income, and average annual change in critical backlog per $\mathrm{m}^{2}$ per Trusts also depend on the base values of backlog (i.e. Trusts with relatively low critical backlog are more able to keep it low, while those with a high starting baseline either: succeed in marginally lowering their critical backlog; or get into increasingly difficult situations). The same was concluded as part of the parallel quantitative study (Mills et al., 2015).

NHS assets investment management strategies tended to be medium-term (i.e. 3-5 years) but were very different between the seven Trusts. The interviews confirmed that those not significantly spending on backlog were accumulating critical backlog. Only one Trust had in place an annual programme for non-recurrent investment from surplus. Three of the Trusts had assets funded under PFI, thus demonstrating that while driving down CIR (i.e. contractual obligation) PFI was among the causes of backlog, highest risks and non-compliance accumulation in the delivery of "affordability strategy”.

High-risk management strategies were described as positive. Although five Trusts identified the importance of managing risk, rather than eradicating high and significant risk-based backlog, only the successful Trusts (i.e. low income-low backlog) was managing backlog and risk in alignment with a long-term strategic plan and annual rolling programme of batched investment to address specific highrisk systems and components. The importance of not reducing backlog prior to significant capital investment and demolition rather managing it instead was considered as delivering good value for money for the Taxpayer. Half of the high income-high backlog sample Trusts declared "clinical development" had been in the past a more viable way to eradicate high risks than maintenance.

Systematic application of CIR methodology was reported as making a significant difference. All 
seven Trusts, irrespective their 'income-backlog' category, reported the consistent use of the DH riskadjusted backlog methodology, but only two of the low income-high backlog highlighted the need for like-to-like comparator benchmarks from a wider network than the region. Trusts with consistently low backlog had a rolling programme of capital investment, based on risk-prioritisation using the DH methodology. The interviews also generated evidence on the Trusts' use of $\mathrm{PAM}^{7}$ (NHS, 2013) to enable prioritisation of risks and Trusts highlighted the importance of regular, expert and dynamic risk assessment towards asset management.

Investment priorities in technical or clinical infrastructure systems were regarded as positive strategic actions by six of the seven Trusts. A key role in keeping backlog maintenance at low manageable levels was delivering appropriate routine maintenance of key engineering systems and components, which were perceived as elements of risk within the assets. Electrical, CHP and boilers were reported among top priorities by low income-high backlog sample interviews. Operating theatres and imaging departments were also commonly reported in strong need of capital investment.

\section{Constraints in addressing CIR}

Capital and revenue availability were raised as driving Trusts' strategic approach, thus impacting on the sustainability of possible actions. Four out of the seven Trusts (including $100 \%$ of low income-low backlog category) stated capital availability as the main constraint to establishing a successful strategy. Time scale and responsiveness of the actions were reported as making the difference (i.e. delays in receiving available capital compromised the management strategy effectiveness). In the high backlog categories (i.e. low and high income) the capital generated form depreciation was mostly spent on non-estates investment (e.g. IT). The low income categories (i.e. low and high backlog) did not consider the revenue a viable option to address CIR, while two out of two in the high income-high backlog category claimed insufficient funding among the major constraints.

Clinical service delivery strategies emerged as a major constraint to effective management of critical backlog. All seven Trusts had strong views that eradication of high and significant risks would not deliver quality of service if not linked to clinical service delivery. The condition of "functional suitability" of a hospital (i.e. fit-for-purpose) would not be achieved even in the absence of high and significant risks (i.e. compliant with regulation) as service change and growth will create new risks over time. The Six-Facet ${ }^{8}$ survey was reported as "adrift" in such a circumstance.

Team capability and responsibility was identified as a constraint by five of Trusts, with a higher percentage among those who reported high backlog levels. They reported lack of professional and executive capabilities in the Trusts' Boards and external bodies (e.g. PFI teams and Six-Facet Condition survey consultants). Lack of foresight and extremely high turnover were also ascribed as causes of unsustainable CIR strategies in one of high income-high backlog category.

Impact on clinical and patient services was difficult to demonstrate for two Trusts and two others did not provide a clear answer. Yet the remaining three confirmed that not targeting high and significant risks would impact on clinical and patient services, and therefore suggested how service delivery added a degree of complexity to addressing CIR.

\section{Foundation Trust (FT) detailed case study: best practice}

Chesterfield Royal NHS FT (i.e. interview No. 1) had one of the lowest backlog costs (see Figure I): backlog per occupied floor area was only $£ 3.25 / \mathrm{m}^{2}$ in $2006 / 07$; rising to $£ 5.92 / \mathrm{m}^{2}$ in $2010 / 11$. The percentage of income re-invested on backlog maintenance against the total backlog cost per occupied floor area was around $0.5 \%$ in 2010/11, as depicted in red in Figure II. The Trust's actual backlog investment was higher than the reported total backlog cost (high, significant, moderate and low) although it had no high or significant backlog as illustrated in Figure III.

\section{[insert Figure I.a and I.b]}

\footnotetext{
${ }^{7}$ Premises Assurance Model (PAM) is a NHS England management tool to assess safety and efficiency performance of the estate and facilities services.

${ }^{8}$ The Six-Facet survey is an assessment methodology based on use, condition and compliance fit-for-purpose of assets recommended to NHS organisations to improve performance of the estate (HBN 00-08 Part A: Strategic framework for the efficient management of healthcare estates and facilities).
} 


\section{[insert figure II]}

To prevent backlog maintenance and adopt a long-term strategically planned estate investment, Chesterfield Royal developed its first detailed estates strategy in 2000 (i.e. 15 year old site) based on the 1999 DH framework "Developing an estate strategy" and identified a three-phase capital investment plan:

- upgrade and developments;

- building repairs and decoration; and

- life-cycle replacement programme.

Following achievement of FT status in 2005 and specific concerns regarding opportunities to finance its capital programme without affecting its estate's life-cycle and infrastructure future investment, the Board made a long-term commitment to supporting the estates strategy "surplus for a purpose" which reflected how the Trust planned its finances around the need to generate an operating financial surplus that would be invested back into the estate. In 2007, the FT developed a five-year site development plan, designed to ensure a co-ordinated approach to dealing with increasing pressures including:

- $\quad$ ageing site with multiple life-cycle replacement requirements occurring simultaneously;

- increased legislative requirements on infrastructure management and design;

- clinical strategy requiring increase in large scale site expansion projects causing a decrease in the availability of life-cycle and infrastructure capital availability; and

- site expansion taking infrastructure services beyond capacity.

This approach was continued and refined on a continual basis, resulting in an overall backlog maintenance of under $£ 300 \mathrm{~K}$ in 2011/12, all of which resourced and programmed in the FT’s capital three-year plan. In 2013 (i.e. 28 year old site), the Trust ensured an integrated long-term approach to its site development and upkeep, which took into consideration all expansion, clinical disruption, infrastructure, life-cycle and decant issues, to keep adequate investment levels to the backlog risklevels, as reported in Figure III.

\section{[insert figure III]}

The FT's use of surplus in a capital programme on a non-recurrent basis and investment, enabled risk to be managed by allocating annual capital expenditures to highest risk items as part of a fiveyear plan. Regular capital investment from surplus kept backlog low. Revenue spend was not considered as a means of investing in capital. The FT generated revenue out of patient care contracts. They re-invested it in immediate infrastructure maintenance plan, saving some to be invested in the future (which will become the actual surplus). "Out of $£ 1$, they would invest $£ 0.96$ and save $£ 0.04$ to be re-invested as surplus".

Having the financial resources was reported as being a conditio-sine-qua-non but not enough to on its own to manage backlog maintenance effectively. In order to sustainably manage estate life-cycle and infrastructure programmes (i.e. backlog) specific elements also needed to be in place:

- adequate time to effectively plan and deliver the works;

- estates management resource to deliver the works;

- financial resources committed in advance; and

- links with clinical service development and delivery strategies to ensure service contingencies or decant facilities.

Investment into its estate infrastructure, building fabric and life-cycle replacement of plant and equipment, despite the relatively new estate, was essential in the continued delivery of high-quality patient care in top-class facilities for the Trust. Furthermore, links with service development strategies ensured that essential life-cycle and infrastructure works could be coordinated whilst other upgrades were undertaken to minimise disruption and make the most effective use of resources.

\section{Discussion}

The positive CIR strategies, as identified through the interviews, had to also deal with the prevailing 
financial constraints, which ultimately drive CM rather than PM, in line with what has been observed in literature. Thus, despite the increased risk of harm and limited efficiency, significant barriers to the implementation of best practices are still present. Among those: planning and committing time and resources to deliver works; and linking works to clinical service development and delivery strategies. Although the interviews did not directly detect issues with the DH methodology in use, but acknowledged it as a positive strategy since being shared across the NHS Trusts, the lack of data at building and component level undermined the theoretical validity of the process.

Chesterfield Royal confirmed that when obstacles (e.g. time constraints) are overcome and positive strategies (e.g. good baseline position, responsive management board and continuous planned investments) are in place, best practices for sustainable management of backlog maintenance are more likely to be achieved. Effective and long-term approaches to capital investments based on accurate past data (e.g. use of surplus on non-recurrent basis when available) may help prevent future accumulation of backlog.

The insightful findings from the interviews were appraised against the best practice achieved by the DCS, which revealed six emerging balanced actions for sustainable management across NHS built assets, as reported below. These actions highlight the need for a consistent, pro-active and long-term strategic approach to management of backlog maintenance in healthcare estates, in a time in which the UK policy agenda is targeting infrastructure operational efficiency and in which the organisations are longing for a systematic application of more comprehensive methodologies.

Knowledge and accountability. Trusts are capable of identifying maintenance risk categories and are willing to put in place routine maintenance, limiting corrective and avoiding accumulation of backlog. However, staff capability and estates team responsibility can put operational strategies at risk, due to excessive turnover and lack of foresight. Professional/technical judgement is essential but requires quality assurance and accountability systems in place.

Appropriate methodology. Despite the DH methodology for managing backlog maintenance and risk-adjusted formula, common practices revealed inaccurate and ambiguous application to determine individual Trust position. Other elements not directly related to the built assets can deliver sustainable and efficient NHS asset management. Intensity of a building's use and occupancy, and time of the year that the facility is in use are two elements of the M-OUF formula that are not considered in the DH methodology.

Shared performance metrics. A common set of performance metrics for each building/block (and external areas) should be envisaged to allow comparison from a wider network rather than only regional, so that best practices can be shared, transferred and reflected in capital investment programmes, where alike conditions are present. A nationwide comparable and proactive investment strategy towards routine maintenance is advocated.

Regular investments. Regular investments can keep backlog low, and opportunities to consistently support capital programmes should be sought, rather than counting on Trusts' revenues. Appropriate types and levels of investments depend on each Trust's unique starting position, as the 'ageing factor' impacts on healthcare buildings. Nonetheless, they should prioritise the eradication of critical levels of backlog, since low and moderate risks are part of the 'natural ageing' of the assets and their levels do not harm patients, staff and visitors if adequately managed. Conversely, critical risk areas and engineering systems would immediately impact clinical and patient services.

FT status and PFI schemes. FT status can add continuity of investment as the capital can be spent outside the constraints of the financial year and can improve financial positive status of the organisation, as suggested by Chesterfield Royal. Batched procurement can help to deliver economies of scale on specific elements across sites within a Trust. The way in which maintenance, refurbishment or new design are financed imposes new considerations, as the interviews have highlighted how major PFI schemes allowed for reduction of the existing amount of critical backlog only after completion.

Service delivery strategies. Time scale and responsiveness are key to sustainable management of backlog maintenance. Best practices should provide useful lessons against undesirable events and potential failings to NHS assets management strategies. Planned investments over long-term schedules should maximise estates pro-activity when opportunities arise. Moreover, Chesterfield Royal confirmed that links with clinical service delivery and service development strategies were among the key elements in estates life-cycle and infrastructure programmes, suggesting further 
elements that could dictate future strategic approaches besides mere economic efficiencies.

\section{Limitations}

This paper presents the outcomes of seven interviews and one DCS, providing constraints to wider applicability of the suggested actions. In-depth analysis of a larger sample of Trusts should be taken in order to set national best practices.

This study did not identify any causal relationship between levels of investments as percentage of Trust income and levels of backlog maintenance eradicated. Metrics to estimate at asset, building and component level should be put in place before conducting further analysis.

\section{Conclusions}

The study identified positive strategies for and major constraints against achieving responsive longterm strategies for backlog maintenance. Building age profile has a significant impact on accumulation of critical backlog and could be an essential factor to determine funds to upkeep assets, through PM and CM. Building type and identification of sustainable actions to overcome inefficiencies is to be taken in account, as suggested by the IHS.

This research endorses sustainable management of NHS built assets backlog maintenance to enable all Trusts to provide good quality care to patients, in a safe working environment for the staff and those who visit the patients. What is highly advocated for the NHS is evaluating where the boundaries between CM and BM stand, in order to limit the first and avoid accumulation of the latter, once eradicated the high and significant risks, and supporting long-term approaches in accordance to each Trust unique financial, operational and clinical strategy to manage and harness the potential of their capital assets to realistically and appropriately deliver value for all stakeholders over time.

Estates type, age and location of the buildings, together with type and use need to be further explored, as the IHS has done, to implement current management strategies and deliver sustainability over the life-cycle of the individual building/block (and external areas), thus of the Trusts' built assets.

\section{Acknowledgments [insert acknowledgments]}




\section{References}

Appleby, J., Crawford, R.and Emmerson, C. (2009), How cold will it be? Prospects for NHS funding: 2011-2017, The King's Fund and the Institute for Fiscal Studies.

Asset Management Service Unit (2010), Guidelines for backlog maintenance, Queensland, Queensland Government.

Baillie, J. (2013), "Young blood vital to sector's future ", Health Estate Journal of the Institute of Healthcare Engineering and Estate Management, 67, 2, 37-43.

Baker, L. C., Phibbs, C. S., Guarino, C., Supina, D.and Reynolds, J. L. (2004), "Within-year variation in hospital utilization and its implications for hospital costs", Journal of Health Economics, 23, 1, 191-211.

Building Policy Unit (2012), Maintenance Management Framework. Policy for the maintenance of Queensland Government buildings, Brisbane, Queensland Department of Housing and Public Works.

Burke, L. A.and Miller, M. K. (2001), "Phone Interviewing as a Means of Data Collection:

Lessons Learned and Practical Recommendations", Forum Qualitative

Sozialforschung / Forum: Qualitative Social Research [Online], 2, available at: http://www.qualitative-research.net/index.php/fqs/article/view/959.

Department of Health (2012a), Annual Report and Accounts 2011-12, London, Department of Health.

Department of Health (2012b), Estates Return Information Collection (ERIC) 2011/12, Leeds, NHS Information Centre for Health and Social Care.

Department of Health (2014), Hospital Estates and Facilities Statistics 2013-14, Leeds, NHS Information Centre for Health and Social Care.

DH/NHS Finance Performance and Operations (2010), The Operating Framework for the NHS in England 2011/2012, Crown.

Francis, R. (2013), Report of the Mid Staffordshire NHS Foundation Trust Public Inquiry, London.

Harker, R. (2012), NHS funding and expenditure, House of Commons Library.

Indian Health Service - OEHE (2007), "Technical Handbook for Environmental Health and Engineering ", Maintenance and Improvement Funding Allocation, 1-10.

Keogh, B. (2013), Review into the quality of care and treatment provided by 14 hospital trusts in England: overview report, NHS.

Lafond, S. (2015), Current NHS spending in England, London, UK, The Health Foundation.

Langford, M. (2009), "A model approach advocated", Health estate, 63, 10, 37-42.

Lord Carter of Coles (2015), Review of Operational Productivity in NHS providers. Interim Report., Department of Health.

Mills, G. R. W., Deka, L., Price, A. D. F., Rich-Mahadkar, S., Pantzartzis, E.and Sellars, P. (2015), "Critical infrastructure risk in NHS England: predicting the impact of building portfolio age", International Journal of Strategic Property Management, 19, 2, 159-172.

NHS (2013), The NHS Premises Assurance Model (NHS PAM), Department of Health,

NHS (2014), Five Year Forward View, NHS England.

NHS Estates (2004a), "Best practice advice - Establishing and Managing Backlog".

NHS Estates (2004b), "A risk-based methodology for establishing and managing backlog ".

Novick, G. (2008), "Is There a Bias Against Telephone Interviews In Qualitative Research?", Research in nursing \& health, 31, 4, 391-398.

Royal Institution of Chartered Surveyors (2012), "RICS draft guidance note - Building maintenance: startegy, planning and procurement", Introduction.

Teddlie, C.and Yu, F. (2007), "Mixed Methods Sampling: A Typology With Examples", Journal of Mixed Methods Research, 1, 1, 77-100.

Weninger-Vycudil, A., Litzka, J., Schiffmann, F., Lindermann, H. P., Haberl, J., Scazziga, I., Rodriguez, M., Hueppi, A.and Jamnik, J. (2009), Maintenance backlog estimation and use, Road Eranet.

West, D. (2009), "NHS buildings face 4.04bn maintenance backlog", Health Service Journal. 
Figure I. a) and b) National benchmark - Total backlog cost per occupied floor area (ERIC data)

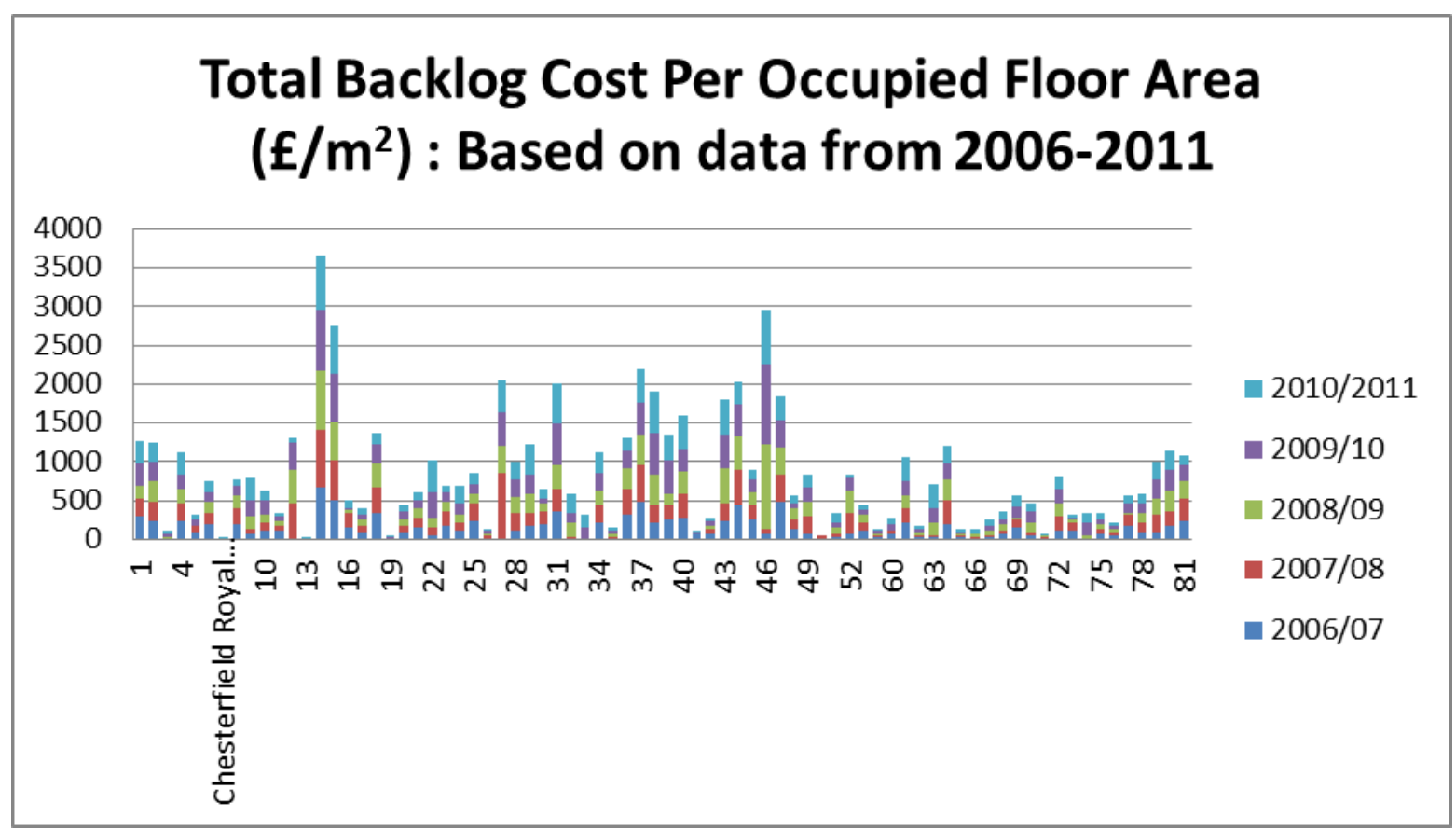

\section{Total Backlog Cost Per Occupied Floor Area $\left(\mathrm{f} / \mathrm{m}^{2}\right)$ : Based on data from 2006-2011}

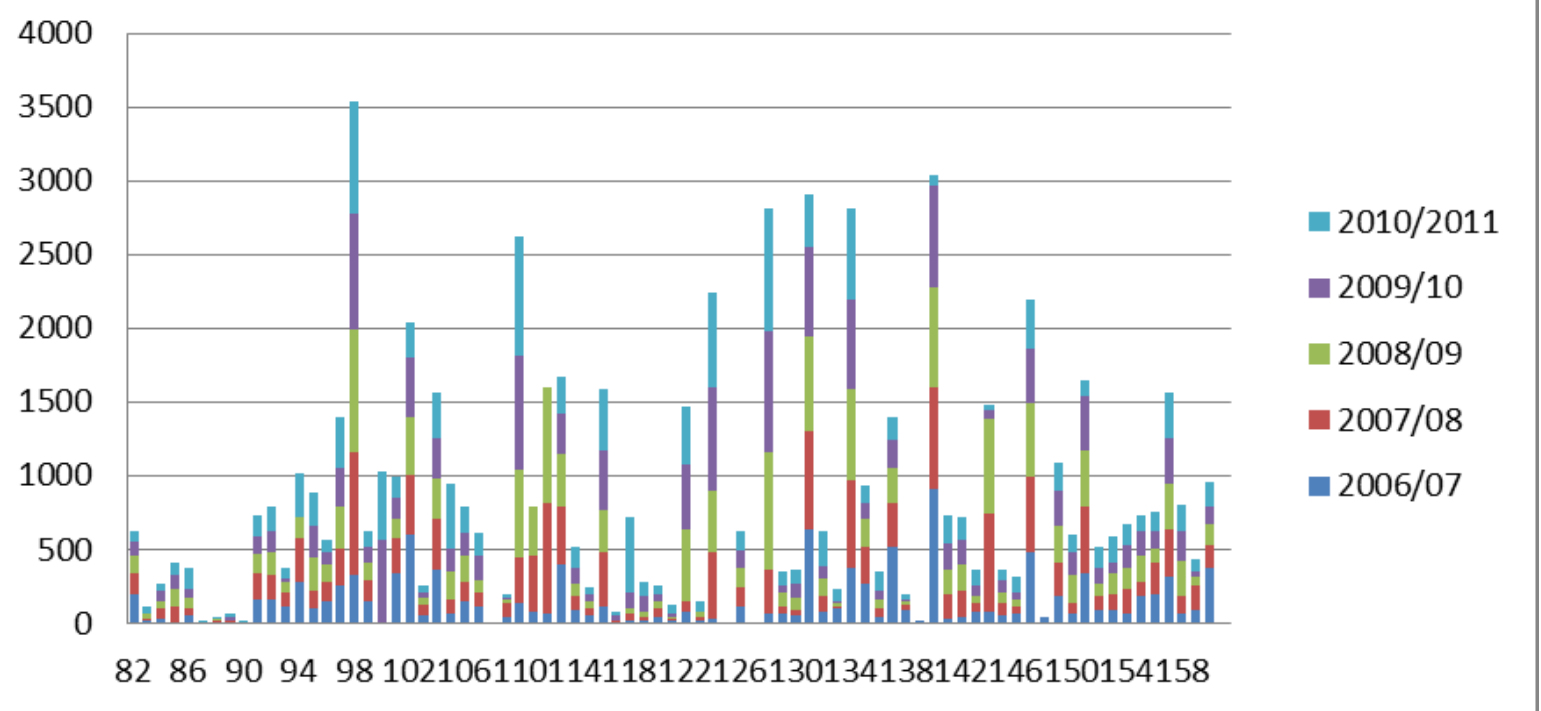


Figure II. National benchmark - Investment as percentage of income spent on backlog and backlog/m²

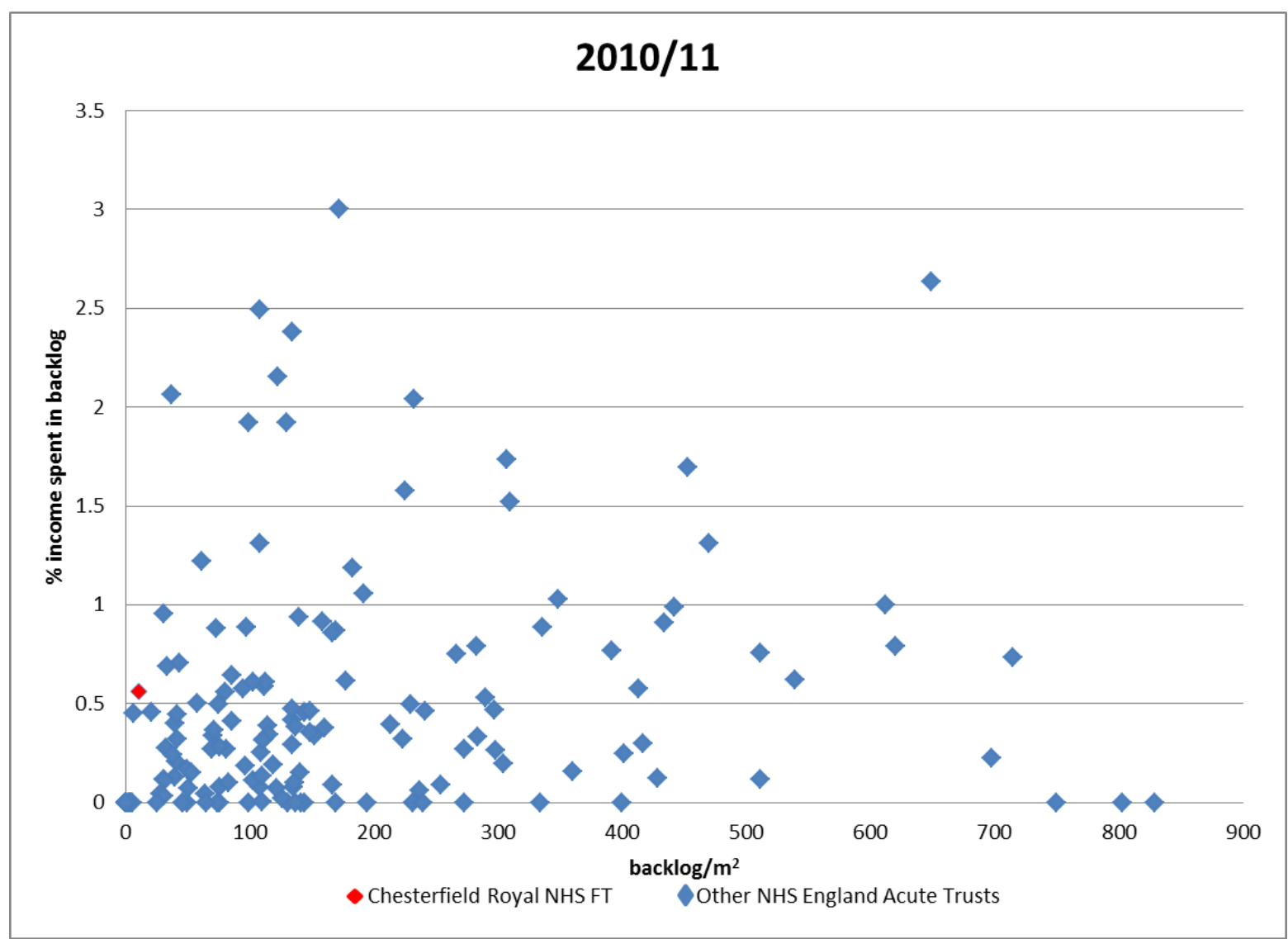


Figure III. Chesterfield Royal NHS FT level-backlog cost spent on high, significant, moderate and low risk categories vs. investment (ERIC data)

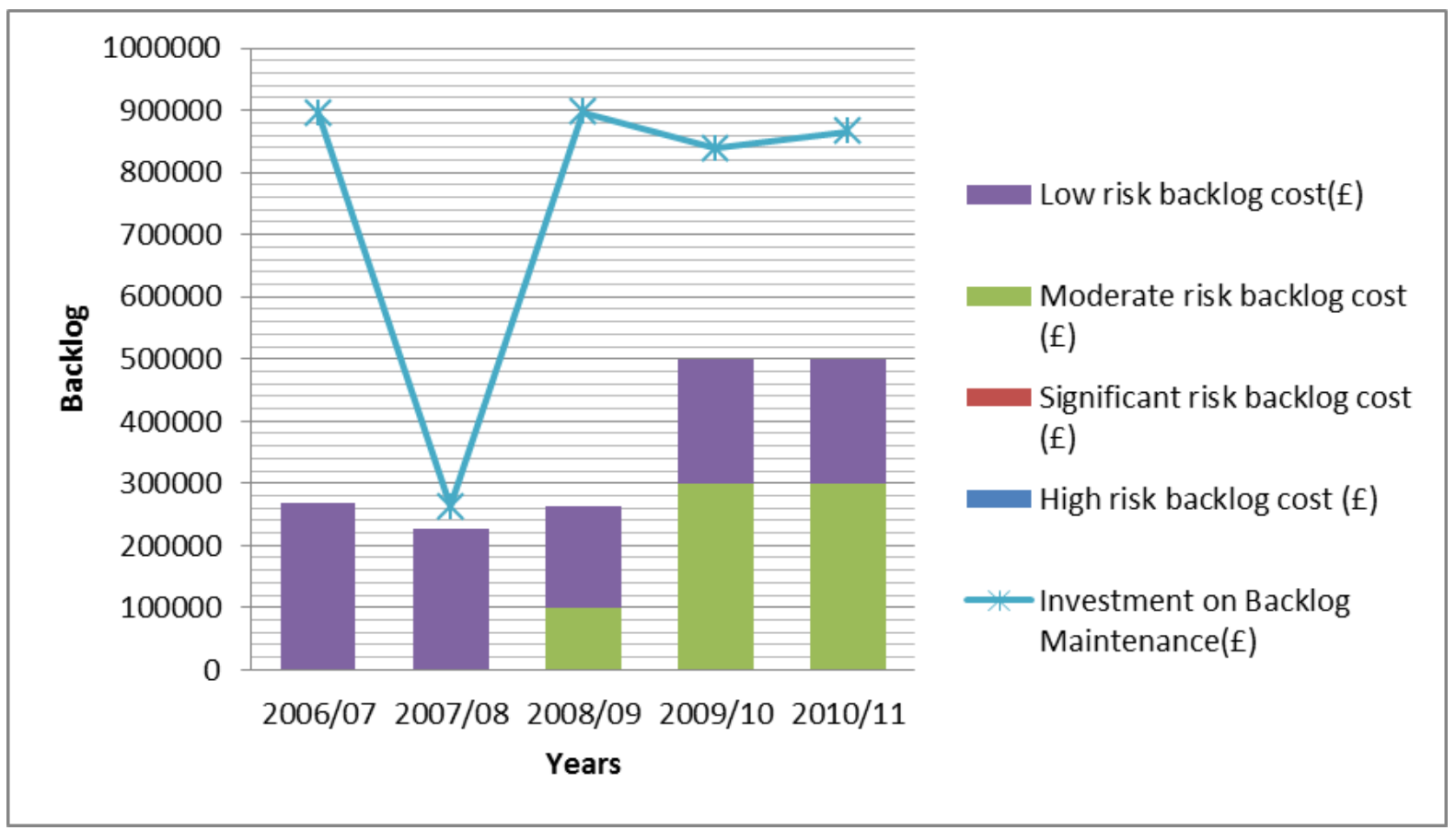


Table I. Summary of elements taken into account and limitations type and level to estimate routine

\begin{tabular}{|c|c|c|c|}
\hline & Aim & Elements taken into account & Limitations type and level \\
\hline $\begin{array}{l}\text { Non-critical backlog } \\
\text { (i.e. backlog cost } \\
\text { relating to low and } \\
\text { moderate risk) }\end{array}$ & $\begin{array}{l}\text { Remaining } \\
\text { expectancies } \\
\text { (i.e. years in } \\
\text { condition B }\end{array}$ & $\begin{array}{l}\text { Age of the asset } \\
\text { Building construction dates } \\
\text { Building services installation dates } \\
\text { Effectiveness of planned } \\
\text { maintenance } \\
\text { Evidence of residual robustness } \\
\text { Evidence of deterioration } \\
\text { Historical information on failures } \\
\text { Information on tests carried out } \\
\text { over current life } \\
\text { Knowledge of current and } \\
\text { impending mandatory fire safety } \\
\text { requirements and statutory safety } \\
\text { legislation }\end{array}$ & $\begin{array}{l}\text { Data access - Asset } \\
\text { Data access - Building } \\
\text { Data access - Building } \\
\text { Objective method - Component } \\
\text { Objective method - Component } \\
\text { Objective method - Component } \\
\text { Data access - Building } \\
\text { Data record - Component } \\
\text { Data record - Component }\end{array}$ \\
\hline $\begin{array}{l}\text { Modified University } \\
\text { of Oklahoma } \\
\text { Formula (M-OUF) }\end{array}$ & $\begin{array}{l}\text { Routine } \\
\text { maintenance } \\
\text { (i.e. cost) }\end{array}$ & $\begin{array}{l}\text { Current location of the building } \\
\text { (location adjust factor) } \\
\text { Intensity of use and occupancy of } \\
\text { the building (maintenance factor } \\
\text { based upon use and occupancy) } \\
\text { Time of the year that the facility is } \\
\text { in use } \\
\text { Total space of owned (gross } \mathrm{m}^{2} \text { ) or } \\
\text { leased (net } \mathrm{m}^{2} \text { ) buildings } \\
\text { Type of building construction } \\
\text { (maintenance factor based on type) } \\
\text { Replacement cost per square metre } \\
\text { of the facility }\end{array}$ & $\begin{array}{l}\text { Data access - Building } \\
\text { Data record - Building } \\
\text { Data record - Building } \\
\text { Data access - Building } \\
\text { Data access - Building } \\
\text { Data record - Building }\end{array}$ \\
\hline
\end{tabular}


Table II. Summary of case studies results from the interviews

\begin{tabular}{|c|c|c|c|c|c|c|c|c|}
\hline \multirow{3}{*}{ 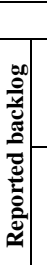 } & & 1 - Chesterfield & 2 & 4 & 5 & 6 & 3 & 7 \\
\hline & ڤ્气 & $\begin{array}{l}\text { Low Income - } \\
\text { Low Backlog }\end{array}$ & \multicolumn{4}{|c|}{ Low Income - High Backlog } & \multicolumn{2}{|c|}{ High Income - High Backlog } \\
\hline & $\underset{\frac{\pi}{\pi}}{\frac{\pi}{\pi}}$ & Accurate. & Accurate. & $\begin{array}{l}\text { In-accurate. } \\
\text { External } \\
\text { consultancy } \\
\text { reporting. }\end{array}$ & $\begin{array}{l}\text { In-accurate prior } \\
\text { to } 2009 / 10 \text {. } \\
\text { Accurate post. }\end{array}$ & In-accurate. & $\begin{array}{l}\text { In-accurate. } \\
\text { Variances during } \\
\text { times of } \\
\text { reconfiguration }\end{array}$ & Accurate. \\
\hline \multirow{4}{*}{ 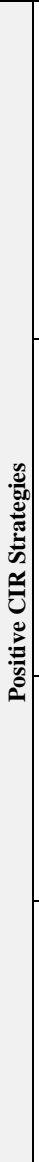 } & 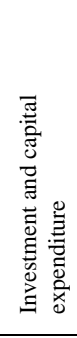 & $\begin{array}{l}\text { Long-term } \\
\text { strategy /3-5 } \\
\text { year planning to } \\
\text { match surplus. } \\
\text { Annual non- } \\
\text { recurrent } \\
\text { investment from } \\
\text { surplus. Limited } \\
\text { new build. }\end{array}$ & $\begin{array}{l}2-3 \text { year estates } \\
\text { strategy and a 2- } \\
5 \text { year } \\
\text { development } \\
\text { control plan. } \\
\text { Significant } \\
\text { reconfiguration } \\
\text { and further } \\
\text { rationalisation. } \\
\text { Some new build } \\
\text { units / } \\
\text { departments. }\end{array}$ & $\begin{array}{l}\text { New } 2010 \text { PFI } \\
\text { handover. In the } \\
\text { years preceding } \\
\text { investment fell. } \\
\text { The majority of } \\
\text { older buildings } \\
\text { were decanted } \\
\text { and demolished } \\
\text { as a part of the } \\
\text { PFI. }\end{array}$ & $\begin{array}{l}\text { Change in risk- } \\
\text { adjusted backlog } \\
\text { method used (i.e. } \\
\text { DH to Langford) } \\
\text { resulted in a } \\
\text { reduction in the } \\
\text { reported high } \\
\text { and significant } \\
\text { backlog (the } \\
\text { total remains the } \\
\text { same). }\end{array}$ & $\begin{array}{l}\text { In a process of } \\
\text { procuring a new } \\
\text { PFI hospital } \\
\text { between the two } \\
\text { old sites. There } \\
\text { was a strategy of } \\
\text { backlog } \\
\text { accumulation } \\
\text { (e.g. manage } \\
\text { backlog at safe } \\
\text { levels). }\end{array}$ & $\begin{array}{l}\text { Affordability } \\
\text { strategy (i.e. sale } \\
\text { of existing } \\
\text { buildings to } \\
\text { reduce backlog } \\
\text { prior to } \\
\text { construction of } \\
\text { new PFI } \\
\text { building). }\end{array}$ & $\begin{array}{l}\text { 3-5 year strategy } \\
\text { to build new } \\
\text { accommodation } \\
\text { (i.e. facility to } \\
\text { decant). } \\
\text { Refurbishment } \\
\text { and replacing } \\
\text { parts of older } \\
\text { estate ( } 40 \text { years } \\
\text { old) - merging } \\
\text { two wards into } \\
\text { one. }\end{array}$ \\
\hline & 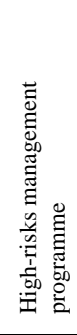 & $\begin{array}{l}\text { Annual } \\
\text { allocation of } \\
\text { capital to highest } \\
\text { risk items. } \\
\text { Rolling } \\
\text { programme of } \\
\text { larger schemes. } \\
\text { Batched } \\
\text { procurement to } \\
\text { deliver } \\
\text { economies of } \\
\text { scale. }\end{array}$ & $\begin{array}{l}\text { Priority placed } \\
\text { on eradicating } \\
\text { high risk } \\
\text { backlog and then } \\
\text { managing risks } \\
\text { elsewhere. }\end{array}$ & $\begin{array}{l}\text { PFI introduced } \\
\text { proactive } \\
\text { (preventative/pla } \\
\text { nned) and } \\
\text { reactive } \\
\text { (corrective } \\
\text { maintenance), as } \\
\text { contractual } \\
\text { obligation to } \\
\text { avoid failure and } \\
\text { keep systems in } \\
\text { good condition. }\end{array}$ & NR & $\begin{array}{l}\text { Managing risk } \\
\text { rather than } \\
\text { backlog } \\
\text { eradication. } \\
\text { Specifically } \\
\text { identifying } \\
\text { issues that } \\
\text { physically led to } \\
\text { high risk } \\
\text { backlog. }\end{array}$ & $\begin{array}{l}\text { Priority on } \\
\text { immediate } \\
\text { problems. It is a } \\
\text { positive strategy } \\
\text { to focus capital } \\
\text { on new build, } \\
\text { although this } \\
\text { does introduce } \\
\text { some issues of } \\
\text { higher risk } \\
\text { backlog. }\end{array}$ & $\begin{array}{l}\text { Past strategy } \\
\text { focussed on } \\
\text { clinical } \\
\text { development } \\
\text { rather than in } \\
\text { maintenance. } \\
\text { Change now } \\
\text { driven by the } \\
\text { need to eliminate } \\
\text { risks and } \\
\text { maintain } \\
\text { compliance. }\end{array}$ \\
\hline & 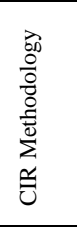 & $\begin{array}{l}\text { DH risk-based } \\
\text { methodology. } \\
\text { Used for 5-10 } \\
\text { years. }\end{array}$ & $\begin{array}{l}\text { DH risk-based } \\
\text { methodology, } \\
\text { using a common } \\
\text { approach allows } \\
\text { comparison. }\end{array}$ & $\begin{array}{l}\text { DH risk-based } \\
\text { methodology. In } \\
2009 \text { and } 2012 \text { a } \\
\text { desk study was } \\
\text { completed to } \\
\text { identify areas of } \\
\text { highest risk. }\end{array}$ & $\begin{array}{l}\text { The Langford } \\
\text { method. } \\
\text { Comparison } \\
\text { should be with } \\
\text { comparative } \\
\text { peers from a } \\
\text { wider network } \\
\text { than the region. }\end{array}$ & $\begin{array}{l}\text { DH risk-based } \\
\text { methodology. } \\
\text { Regular and } \\
\text { dynamic risk } \\
\text { assessment of } \\
\text { specific } \\
\text { engineering } \\
\text { systems. }\end{array}$ & $\begin{array}{l}\text { DH risk-based } \\
\text { methodology }\end{array}$ & $\begin{array}{l}\text { DH risk-based } \\
\text { methodology. }\end{array}$ \\
\hline & 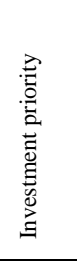 & $\begin{array}{l}\text { - Theatres; } \\
\text { - flat roofs; } \\
\text { - plant. }\end{array}$ & $\begin{array}{l}\text { - Boilers; } \\
\text { - theatres; } \\
\text { - infrastructure } \\
\text { (e.g. soil } \\
\text { stacks and } \\
\text { electrical); } \\
\text { - CHP plant. }\end{array}$ & $\begin{array}{l}\text { - Mechanical } \\
\text { services; } \\
\text { - web services; } \\
\text { - boilers; } \\
\text { - electrical / } \\
\text { emergencies } \\
\text { lighting; } \\
\text { - domestic hot } \\
\text { water. }\end{array}$ & NR & $\begin{array}{l}\text { - Electrical } \\
\text { infrastructure }\end{array}$ & $\begin{array}{l}\text { - Theatres; } \\
\text { - A\&E; } \\
\text { - X-ray and } \\
\text { radiography } \\
\text { departments. }\end{array}$ & $\begin{array}{l}\text { - Boiler house; } \\
\text { - CHP; } \\
\text { - lifts; } \\
\text { - wards. }\end{array}$ \\
\hline 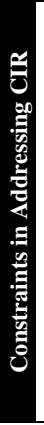 & 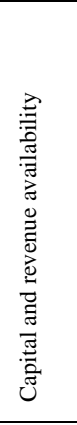 & $\begin{array}{l}\text { Revenue not } \\
\text { considered as a } \\
\text { means of } \\
\text { investing in } \\
\text { capital. } \\
\text { Regular capital } \\
\text { investment from } \\
\text { surplus. Limited } \\
\text { available capital } \\
\text { in the future. FT } \\
\text { status provided } \\
\text { investment, } \\
\text { flexibility and } \\
\text { fewer } \\
\text { limitations. }\end{array}$ & $\begin{array}{l}\text { Revenue not } \\
\text { considered an } \\
\text { option. Capital } \\
\text { non-availability } \\
\text { as, capital } \\
\text { receipts from } \\
\text { land and } \\
\text { property sales } \\
\text { earmarked to } \\
\text { other areas (e.g. } \\
\text { ICT and } \\
\text { technology). } \\
\text { This escalated } \\
\text { by attempts to } \\
\text { obtain FT status. }\end{array}$ & $\begin{array}{l}\text { Surplus } \\
\text { available in } \\
2005-10, \\
\text { however } \\
\text { investment in } \\
\text { backlog did not } \\
\text { follow this. } \\
\text { Since } 2010 \text { the } \\
\text { PFI is decreasing } \\
\text { the surplus and } \\
\text { money is being } \\
\text { invested up until } \\
\text { 2014. Capital } \\
\text { availability was } \\
\text { a concern. }\end{array}$ & $\begin{array}{l}\text { Internal } \\
\text { competition over } \\
\text { capital budgets: } \\
\text { equipment } \\
\text { replacement; IT } \\
\text { upgrade; and } \\
\text { service } \\
\text { development. }\end{array}$ & $\begin{array}{l}\text { Capital } \\
\text { generated from } \\
\text { depreciation } \\
\text { mostly spent on } \\
\text { non-estates } \\
\text { investment (e.g. } \\
\text { IT). }\end{array}$ & $\begin{array}{l}\text { Capital } \\
\text { availability not a } \\
\text { concern. } \\
\text { Insufficient } \\
\text { funding. } \\
\text { Significant } \\
\text { investment on } \\
\text { ICT and } \\
\text { technology. } \\
\text { Lack of a rolling } \\
\text { and realistic } \\
\text { programme. }\end{array}$ & $\begin{array}{l}\text { Insufficient } \\
\text { funding. Capital } \\
\text { generated from } \\
\text { depreciation } \\
\text { mostly spent on } \\
\text { non-estates } \\
\text { investment (e.g. } \\
\text { IT). Need for } \\
\text { major } \\
\text { investment to } \\
\text { make a step } \\
\text { change (i.e. } \\
\text { significant new } \\
\text { build). }\end{array}$ \\
\hline
\end{tabular}




\begin{tabular}{|c|c|c|c|c|c|c|c|}
\hline 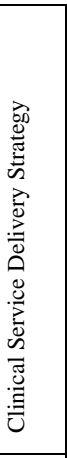 & $\begin{array}{l}\text { Priority to } \\
\text { eradicate High } \\
\text { and Significant } \\
\text { Risk } \\
\text { concurrently } \\
\text { with Clinical } \\
\text { Care Pathway } \\
\text { transformation. }\end{array}$ & $\begin{array}{l}\text { Delivering care } \\
\text { pathway } \\
\text { transformation } \\
\text { with a focus on } \\
\text { backlog } \\
\text { maintenance } \\
\text { reduction. } \\
\text { Eradication in } \\
\text { backlog to } \\
\text { reduce operating } \\
\text { costs (i.e. energy } \\
\text { efficiency and } \\
\text { reduced } \\
\text { maintenance) } \\
\text { and increase } \\
\text { reinvestments. }\end{array}$ & $\begin{array}{l}\text { After backlog is } \\
\text { eradicated, PFI } \\
\text { will provide } \\
\text { assurance of "the } \\
\text { optimum } \\
\text { condition" as } \\
\text { stated in the } \\
\text { contract. } \\
\text { Uncertainty in } \\
\text { knowing if high } \\
\text { and significant } \\
\text { backlog could be } \\
\text { (or need to be) } \\
\text { eradicated, } \\
\text { before achieving } \\
\text { FT status. }\end{array}$ & $\begin{array}{l}\text { Clinical } \\
\text { performance } \\
\text { targets and } \\
\text { waiting lists key } \\
\text { clinical drivers. } \\
\text { Need to address } \\
\text { space utilisation } \\
\text { to create } \\
\text { capacity slack } \\
\text { (i.e. decanting } \\
\text { ward). }\end{array}$ & $\begin{array}{l}\text { Six-Facet } \\
\text { Condition } \\
\text { survey (i.e. fit- } \\
\text { for-purpose) } \\
\text { aimless as } \\
\text { growing in } \\
\text { hospital service } \\
\text { demand impacts } \\
\text { on functional } \\
\text { suitability of the } \\
\text { hospital (i.e. } \\
\text { adequately } \\
\text { maintained } \\
\text { systems. clinic } \\
\text { rooms } \\
\text { overloaded). }\end{array}$ & NR & $\begin{array}{l}\text { Priority to } \\
\text { eradicate high } \\
\text { and significant } \\
\text { risk all together, } \\
\text { prevent it from } \\
\text { getting worse } \\
\text { and then to have } \\
\text { some major } \\
\text { investment, to } \\
\text { make a step } \\
\text { change by } \\
\text { providing some } \\
\text { significant new } \\
\text { build. }\end{array}$ \\
\hline 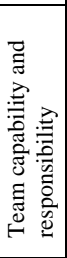 & NR & NR & $\begin{array}{l}\text { Accumulation of } \\
\text { high and } \\
\text { significant risk } \\
\text { may be as a } \\
\text { result of PFI } \\
\text { expertise to } \\
\text { identify the } \\
\text { risks. }\end{array}$ & $\begin{array}{l}\text { Lack of proper } \\
\text { risk assessment } \\
\text { and Six-Facet } \\
\text { Condition } \\
\text { survey prior to } \\
\text { 2009/10 due to } \\
\text { funding } \\
\text { constraints. Desk } \\
\text { study instead. }\end{array}$ & $\begin{array}{l}\text { Business Case } \\
\text { (BC) biases } \\
\text { influence } \\
\text { backlog data } \\
\text { collection. Lack } \\
\text { of professional } \\
\text { and executive } \\
\text { team capability / } \\
\text { responsibility. }\end{array}$ & $\begin{array}{l}\text { Lack of foresight } \\
\text { / Board } \\
\text { responsibility / } \\
\text { high exec team } \\
\text { turnover. }\end{array}$ & $\begin{array}{l}\text { Systematic use } \\
\text { of Six-Facet } \\
\text { Condition } \\
\text { survey and risk- } \\
\text { based analysis } \\
\text { post-major } \\
\text { organisational } \\
\text { reconfiguration } \\
\text { (not in the past). }\end{array}$ \\
\hline 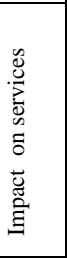 & $\begin{array}{l}\text { Not tackling } \\
\text { critical risk areas } \\
\text { immediately will } \\
\text { impact on } \\
\text { clinical and } \\
\text { patient services. }\end{array}$ & $\begin{array}{l}\text { Difficult to } \\
\text { demonstrate and } \\
\text { quantify. } \\
\text { Evidence from } \\
\text { exemplary Trust } \\
\text { performance } \\
\text { would be useful }\end{array}$ & NR & $\begin{array}{l}\text { Underspend on } \\
\text { some assets } \\
\text { makes them less } \\
\text { safe. }\end{array}$ & NR & $\begin{array}{l}\text { Significant risk } \\
\text { on clinical } \\
\text { outcomes as a } \\
\text { result of break } \\
\text { down (e.g. } \\
\text { operating } \\
\text { theatres losing } \\
\text { power may lead } \\
\text { to patient death). }\end{array}$ & $\begin{array}{l}\text { Difficult to } \\
\text { demonstrate. } \\
\text { Existing estate is } \\
\text { old and } \\
\text { unsuitable (i.e. } \\
\text { does not meet } \\
\text { standards.). }\end{array}$ \\
\hline
\end{tabular}

